\title{
Estimation of Cell Voltage and Power Density for Alcohols Electro-Oxidation on Modified Platinum Surface
}

\author{
Y. Atef*, M. M. Hefny ${ }^{\dagger}$, S. Abd El Wanees*
}

\begin{abstract}
Fuel cell performance was studied with regard to alcohols electro-oxidation on modified platinum under different conditions such as temperature and modification time. This research is aimed to estimate each of cell voltages and power densities as a function of current densities and the other cell parameters. The electrochemical cells operated on the electrooxidation of methanol and ethanol in both $\mathrm{HClO}_{4}$ as an acidic medium and $\mathrm{KOH}$ as an alkaline medium. Applying the definition of electromotive force combined with Ohm's law on the oxidation reaction, power density curves are constructed. Optimum parameters for cell voltage and power density had been determined.
\end{abstract}

Keywords: Methanol, Ethanol, electro-oxidation, modified Pt, cell voltage, power density

\section{Introduction}

The importance of the surface coverage in the behavior of chemically modified electrodes and its effect on different electrochemical parameters was studied in many works [1]. The key for an efficient catalyst treatment is strongly based on the anode material choice.

The electrochemical oxidation process on Pt electrode occurs via oxygen atom transfer from water of the electrolyte to the reactant $(\mathrm{R})$ via oxidized Pt species. The overall processes of anodic oxygen transfer may be represented by the generic reactions [2]:

$$
\begin{aligned}
& \mathrm{Pt}+\mathrm{xH}_{2} \mathrm{O} \rightarrow \mathrm{PtO}_{\mathrm{x}}+2 \mathrm{xH}^{+}+2 \mathrm{x} \mathrm{e}^{-} \\
& \mathrm{PtO}_{\mathrm{x}}+\mathrm{xH}_{2} \mathrm{O} \rightarrow \mathrm{Pt}(\mathrm{OH})_{\mathrm{x}}+\mathrm{x} \mathrm{OH} \bullet \\
& \mathrm{x} \mathrm{OH} \bullet+\mathrm{R} \rightarrow \mathrm{RO}+\mathrm{H}_{2} \mathrm{O}
\end{aligned}
$$

In this mechanism the oxygen transfer involves the hydroxyl radical $(\mathrm{OH} \bullet)$ formed on the electrode surface as a consequence of the intermediate step of the discharge of water [3].

Previously the authors of this article had studied the electro-oxidation of simple alcohols on modified platinum electrode [4]. The alcohols are methanol and ethanol. Modification was made by repetitive cyclic polarization of mechanically polished platinum electrode. The electrolyte is aqueous $0.1 \mathrm{M} \mathrm{HClO}_{4}$ or $\mathrm{KOH}$. This article introduces an approach for estimation of the emf and power that may be obtained from a fuel cell constructed with the tested condition, viz. modified platinum electrode as a catalyst.

Corresponding Author, Chemistry Administration, Cairo, Egypt; jasy9@yahoo.com

Chemistry Department, Faculty of Science, Cairo University, Giza, Egypt.

Chemistry Department, Faculty of Science, Zagazig University, Zagazig, Egypt; \& Chemistry Department, Faculty of Science, University of Tabuk, Tabuk, Kingdom of Saudi Arabia. 
The objective of this work is to exploit the importance of the surface coverage in the electrochemical behavior of Pt surface after its modification by oxide film as well as its effect on cell performance which express the electrochemical oxidation of alcohols. The power density of the cell explored as temperatures, extent of $\mathrm{Pt}$ modification and alcohol concentrations were studied.

\section{Experimental}

The details of the experiments is given elsewhere [4]. As working electrode, pure platinum (0.6 and $0.4 \mathrm{~cm}^{2}$ as a sheet, Aldrich, thermocouple quality) was used. This working electrode was polished with decreasing grades of fine emery papers, degreased with acetone and washed with running distilled water, before its immersion in the test solution. A three compartment cell with a saturated calomel reference electrode (SCE) and a platinum foil auxiliary electrode were used. The electrode potential was controlled by a voltage scan generator, an automatically-controlled electronic Wenking Laboratory Poteniostat (LB 75). DC voltammograms were recorded using Allen, Model 1000 X-Y recorder.

Each experiment was carried out in a freshly prepared solution and with a newly polished electrode surface. After cyclization for a definite time (number of cycles), the electrolyte was replaced by pure $0.1 \mathrm{M} \mathrm{HClO}_{4}, 0.05 \mathrm{M}$ or $0.1 \mathrm{M} \mathrm{KOH}$ free or containing alcohol.

\section{Results and Discussion}

\subsection{Definition of Terms}

In this work at the anodic scan of the CVs, the change of the curves in the presence and absence of the alcohol is due to the alcohol oxidation reaction. Scheme (1), shows a typical cyclic voltammogram for ethanol oxidation.

At the peak $I_{a}$, there are no significant changes in the currents with and without alcohol in $\mathrm{HClO}_{4}$ solutions and appear closed to each others. This indicate that the same reaction occurs in both cases; in absence and presence of alcohol, i.e., the alcohol doesn't produce energy at peak $I_{a}$, so it is related to the hydrogen reaction only and doesn't consume the alcohol for the oxidation reaction, so, it is neglected in concluded the power product. The calculation of the power density is derived by the alcohol electro-oxidation shown in scheme (1).

Using the definition of electromotive force as the voltage developed by any source of electrical energy such as a battery is defined the electrical potential in the cell.

At the peak $\mathrm{II}_{\mathrm{a}}$, where the release of the oxidation current which resulting from the alcohol oxidation reaction is plotted in the region between $E_{o}$ and $E_{p}$ where, $E_{o}$ is the potential before which the minimum current of the oxidation reaction occurs at the onset potential, $E_{s}$, and $E_{p}$ is the potential at which the maximum current density of the oxidation reaction, i.e., the decay of maximum current density, $j_{\max }$. And so, the region between $E_{o}$ and $E_{p}$ can be defined or described as the only different region for the curves at which the oxidation current is reversely proportional to the $E_{o}$ values. Since its release causes the alcohol oxidation reaction which represented in the region under the peak $\mathrm{II}_{\mathrm{a}}$ of alcohol oxidation, after which it diminished and the current is fallen again. 

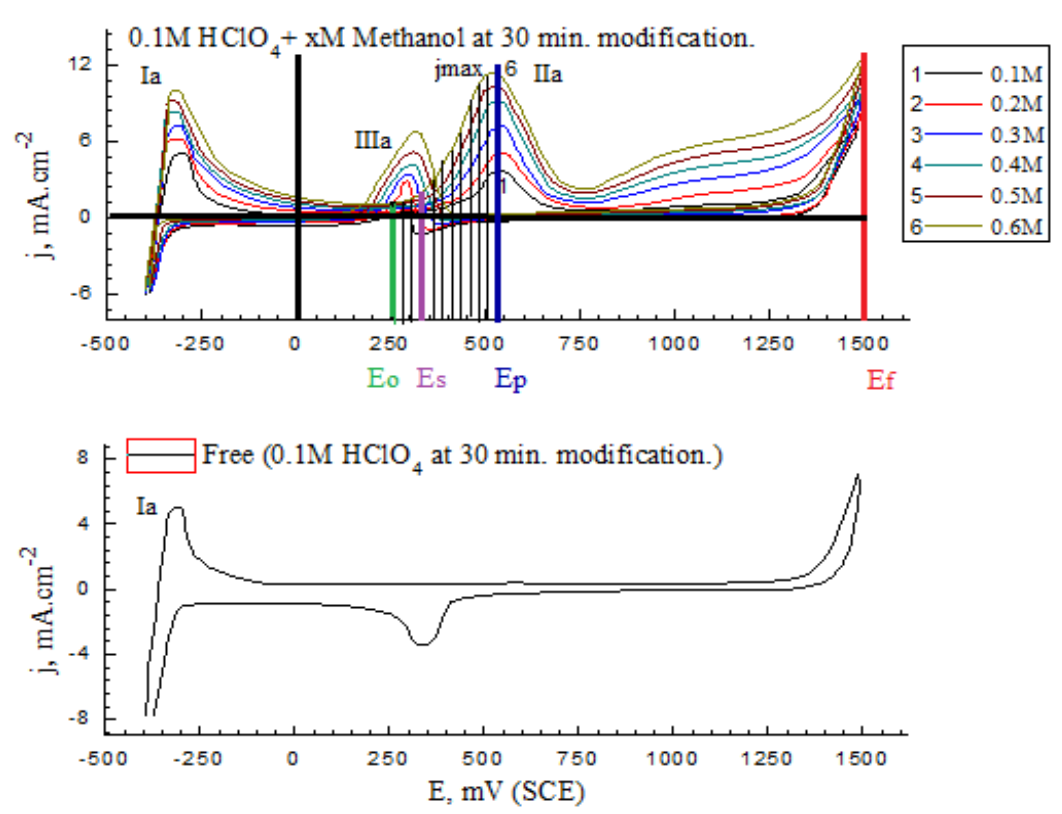

Scheme (1): The schematic diagram for calculation of power density.

\subsection{Formulation of the Approach}

So, it is possible to say that the potential span of the curve between $E_{o}$ and $E_{f}$ at which the differences in the curves with and without alcohol appear and is called "oxidation reaction region". Thus, the difference between $\mathrm{E}_{\mathrm{f}}$ and $\mathrm{E}_{\mathrm{o}}$ can be expressed as the electric driving force; span for the obtainable energy region.

Thus $\mathrm{E}_{\mathrm{p}}$ is finished after $\mathrm{I}_{\mathrm{ox}}$ diminishes due to decay of the anodic current after that and hence, the calculations must limit at this point of $\mathrm{E}_{\mathrm{p}}$ where $\mathrm{I}_{\mathrm{ox}}$ fades.

However, with increasing the current density along the $\mathrm{CVs}$ from $\mathrm{E}_{\mathrm{s}}$ reaching to $\mathrm{E}_{\mathrm{p}}$, the cell loses its driving force. So, the calculation can be stopped at this point where such potential difference cannot affect the current peak which already reached. Conclusively, the calculations can initiate by cell voltage $\left(E_{\text {calculated }}\right)=E_{f}-E_{o}$ until cell voltage $\left(E_{\text {calculated }}\right)=E_{f}-E_{p}$, where the oxidation reaction begins and finishes.

During discharge of the cell, Joule's law can be combined with Ohm's law (V = I.R) to produce alternative expressions for the amount of power that is dissipated: $P=I \cdot V=I^{2} \cdot R=V^{2} / R$, where $\mathrm{R}$ is the electrical resistance. In these calculation, the electric power expressed as electric power density, $\mathrm{P}=\mathrm{j} . \mathrm{V}\left(\mathrm{mW} \mathrm{cm}^{-2}\right)$

The previous researches [5-10] and data which related to $\mathrm{E}_{\text {cell }}$ and power density curves that instrumentally measured during the run, it is noticed that the final value of the current density is much closer to $j_{\max }$ value of the related cyclic voltammogram. Also, it is arranged by the same logical of different conditions in both $E_{\text {cell }} v s . j$ relation and the cyclic voltammogram, i.e., the reaction enhances conditions.

Note that, $\mathrm{j}_{\max }$ value is the important value on which the maximum power density value is depended later, and also, arranged by the same logical of different conditions.

Also, it is found that the same logic of reversible and irreversible proportional for both $\mathrm{E}_{\text {calculated }}$ and power density vs. oxidation current density, respectively, as represent in the instrumentally/computerized curves, i.e., experimentally values. The same consistency of the 
curves is also found except the power density curve falling in the instrumentally/computerized curves and its falling is independent on oxidation current values. So, it isn't taken in consideration.

\subsection{Power Density for Methanol Electro-Oxidation in $\mathrm{HClO}_{4}$}

In this work, the voltage-current density and the power density-current density curves were calculated. The polarization and power density curves of using modified Pt electrode as the anode catalyst are presented in Figs. $(1,2)$. The measurements were made by feeding different methanol concentration mixed with $0.1 \mathrm{M} \mathrm{HClO}_{4}$ to the cell at room temperature, $25^{\circ} \mathrm{C}$, after 30 minutes modification for Pt electrode. The DMFC with higher concentrations for methanol gives better performance than that with lower concentrations in terms of both $\mathrm{E}_{\text {cell }}$ and power density. In the case of $0.6 \mathrm{M}$ methanol, the $\mathrm{E}_{\text {cell }}$ is $1.42 \mathrm{~V}$, i.e., $0.15 \mathrm{~V}$ higher than that of $0.1 \mathrm{M}$ methanol, which is consistent with the onset potential of EOR in CV characterization. The maximum power density for $0.6 \mathrm{M}$ methanol is $10.9 \mathrm{mWcm}^{-2}$, and that for $0.1 \mathrm{M}$ methanol is $3.84 \mathrm{mWcm}^{-2}$.

The polarization and power density curves of the DMFCs at different temperatures of solution (0.6 $\mathrm{M}$ methanol mixed with $0.1 \mathrm{M} \mathrm{HClO}_{4}$ ) are given in Fig. $(3,4)$. With the $30^{\circ} \mathrm{C}$, the $\mathrm{E}_{\text {cell }}$ is $1.43 \mathrm{~V}$ and the peak power density is $17.03 \mathrm{mWcm}^{-2}$, while in the case of $10{ }^{\circ} \mathrm{C}$, the $\mathrm{E}_{\text {cell }}$ is 1.4 $\mathrm{V}$ and the peak power density is $4.85 \mathrm{~mW} \mathrm{~cm}^{-2}$. The results further confirm that the rising of temperature to $30{ }^{\circ} \mathrm{C}$ exhibits a higher catalytic activity toward EOR in acidic media than the low temperature.

Also, we investigate the effect of modification time of Pt electrode on cell performance in 0.6 $\mathrm{M}$ methanol mixed with $0.1 \mathrm{M} \mathrm{HClO}_{4}$; the cell with higher modification time shows higher $\mathrm{E}_{\text {cell }}$ and maximum power density, Fig. $(5,6)$. The cell voltage of increases from $1.41 \mathrm{~V}$ to $1.44 \mathrm{~V}$ as modification time increases from 15 to 60 minutes. Moreover, the peak power density of 60 minutes for $\mathrm{Pt}$ modification is about 1.5times larger than that of 15 minutes from $9.35 \mathrm{mWcm}^{-2}$ to $14 \mathrm{mWcm}^{-2}$.Based on these results, it is found that DMFC can be effectively operated at high methanol concentrations, high temperatures and responsible modified $\mathrm{Pt}$ as anode catalyst with high tolerance for methanol.

\subsection{Power Density for Ethanol Electro-Oxidation in $\mathrm{HClO}_{4}$ :}

Another important class in this study is the effects of ethanol concentration on the cell performance. We evaluated the voltage-current density and the power density-current density curves of DEFC with $0.1 \mathrm{M} \mathrm{HClO}_{4}$, presented in Figs. $(7,8)$, respectively, in order to confirm the possibility for application of a modified Pt catalyst as a function of ethanol concentration. The measurements were made by feeding different amounts of ethanol with $0.1 \mathrm{M} \mathrm{HClO}_{4}$ to the cell at room temperature, after 30 minutes modification for Pt electrode. A higher DEFC performance with higher ethanol concentrations than that with lower ethanol concentrations, in terms of both the calculated $\mathrm{E}_{\text {cell }}$ and power density. The cell with $0.6 \mathrm{M}$ ethanol exhibits higher power density than that of $0.05 \mathrm{M}$ ethanol, as shown in Fig. (8). In the case of $0.6 \mathrm{M}$ ethanol, the power density for $0.6 \mathrm{M}$ ethanol is $12.39 \mathrm{~mW} \mathrm{~cm}^{-2}$.

Typical cell performances obtained with varying temperatures from $\left(10-30{ }^{\circ} \mathrm{C}\right)$ in ethanol electro-oxidation process on the modified Pt electrode. The polarization and power density curves of the DEFCs at different temperatures of solution $(0.6 \mathrm{M}$ ethanol mixed with $0.1 \mathrm{M}$ $\left.\mathrm{HClO}_{4}\right)$ are given in figures $(9,10)$. The use of modified platinum surface as anode catalyst at $10{ }^{\circ} \mathrm{C}$ leads to less electrical performance than that of $30^{\circ} \mathrm{C}$. In case of $30^{\circ} \mathrm{C}$, the power density is $17.9 \mathrm{~mW} \mathrm{~cm}^{-2}$, while in the case of $10^{\circ} \mathrm{C}$; the power density is $7.78 \mathrm{~mW} \mathrm{~cm}{ }^{-2}$. So, the rising of temperature enhances the electrical performance of the DEFC. 
Finally, the 60 minutes of Pt modification as anode catalyst greatly enhances the electrical performance of the DEFC. This system contained $0.6 \mathrm{M}$ ethanol mixed with $0.1 \mathrm{M} \mathrm{HClO}_{4}$, of different modification time for Pt electrode, ranging from (15-60 minutes). The polarization and power density curves of the DEFCs are given in Figs. $(11,12)$. The power density of 60 minutes for Pt modification is about 1.5 times larger than that of 15 minutes from 10.84 $\mathrm{mWcm}^{-2}$ to $16.6 \mathrm{~mW} \mathrm{~cm}^{-2}$.

\subsection{Power Density for Methanol and Ethanol Electro-Oxidation in KOH Solutions}

In this section the effects of both of methanol and ethanol concentration were investigated on the cell performance in $\mathrm{KOH}$ solutions. The evaluated voltage-current density and power density-current density curves of DEFC with $0.1 \mathrm{M} \mathrm{KOH}$, are presented in Figs. (13-16), respectively, in order to confirm the possibility for application of a modified Pt catalyst as a function of methanol and ethanol concentration. The measurements were performed at room temperature, $25^{\circ} \mathrm{C}$ after 15 minutes modification for Pt electrode. Higher cell performance with higher alcohol concentrations, in terms of both the calculated $\mathrm{E}_{\text {cell }}$ and power density. The cell with ethanol exhibits higher power density than that of methanol, as shown in these figures. In the case of $0.5 \mathrm{M}$ ethanol, the power density for is $1.54 \mathrm{mWcm}^{-2}$ and $1.13 \mathrm{~mW} \mathrm{~cm}^{-2}$ for $0.5 \mathrm{M}$ methanol.

Typical electrical performances obtained with decreasing $\mathrm{KOH}$ concentration to $0.05 \mathrm{M}$ with different concentrations of methanol and ethanol in electro-oxidation process on the modified Pt electrode. The polarization and power density curves of the cell are given in figures (17-20). The use of modified platinum as anode catalyst leads to less electrical performance than that of $0.1 \mathrm{M} \mathrm{KOH}$. In this case, the power density is $1.39 \mathrm{mWcm}^{-2}$ for $0.2 \mathrm{M}$ ethanol, while 1.22 $\mathrm{mWcm}^{-2}$ for $0.2 \mathrm{M}$ methanol. So, the decreasing of $\mathrm{KOH}$ concentration enhances the electrical performance of the electro-oxidation processes.

\subsection{Comparison with Previously Published}

\subsubsection{Similarities}

1 - In the $E_{\text {cell, }}$ power density vs. current density relation, it is found that $j_{\max }$ value on which maximum power density is dependent; it is the same value of $\mathrm{j}_{\max }$ in the cyclic voltammograms [11].

2- Also, each current density values of the $\mathrm{E}_{\text {cell }}$ vs. current density relation on which power density dependent is the same that of the cyclic voltammograms [12]. This means that transfer of the cyclic voltammogram to this relation curve as it.

3- It is noticed that the $E_{\text {cell }}$ values in the $E_{\text {cell }}-\mathrm{j}$ curves are almost very close to each other in the most cases of the simple comparison such as uses of different concentrations of the same alcohol on the same catalyst [13], or uses of the same concentration of the same alcohol by different catalysts [14]. And it is noticed in this study.

4- The power density values in the power density-j curves are starting from zero and ending at higher power density values [13], also found in this study.

\subsubsection{Differences}

1- In some $E_{\text {cell, }}$, power density-j curves, it is seen at the end of the relation curves that are almost down to zero voltage and power [11], but not in most cases [12-14], except that produce the lower oxidation currents and thus had low cell voltage and electric power which almost decays to zero such as lower alcohol concentrations and lower catalytic activity.

2- The tail of $E_{\text {cell, }}$, power density-j curves after $j_{\max }$ and max. power density values does not have any importance or aim for the relation understanding and application 
and the onlyjmax and maximum power density values remain the most important to study. So, these differences of the latest $\mathrm{E}_{\text {cell }}$ and power density values in the $\mathrm{E}_{\mathrm{cell}}$, power density- $j$ curves are a limited significant for study and only $j_{\max }$ and highest power density values remain important.

\section{Conclusion}

Modification of Pt by repetitive cyclization enhances the oxidation of methanol and ethanol in $0.1 \mathrm{M} \mathrm{HClO}_{4}$.

The applied conditions have shown that the modified Pt electrode exhibit high catalytic activity for the electro-oxidation process especially with temperature rise and increase of modification time and alcohols concentration.

The suggested approach extracts the portion of the cyclic voltammogram represents the spontaneous oxidation of the fuel. The area corresponding to this portion gives the expected power of the fuel cell. The same trends are observed in $\mathrm{KOH}$ solutions.

1- The estimated cell voltage for the fuel cell operating by the alcohols methanol and ethanol is $0.5 \mathrm{~V}$.

2- The average power density for oxidation of these fuels on modified platinum electrode as a catalyst is $10 \mathrm{~mW} \mathrm{~cm}$.

3- The efficiency of the cell is higher in $\mathrm{HClO}_{4}$ than in $\mathrm{KOH}$ and it increases with rising of temperature and $\mathrm{Pt}$ modification time.

\section{References}

[1] Mamas I. Prodromidis, Ageliki B.Florou, Stella M. Tzouwara-Karayanni and Miltiades I.Karayannis, Electroanalysis, 12 (18), (2000), 1498.

[2] A.Savall, Chimia, 49 (1995) 23.

[3] M. L.Lin, Y. Y. Wang andC. C. Wan, J. Appl. Electrochem., 22 (1992) 1197.

[4] M. M. Hefny, S. Abd El-Wanees and Y. Atef, Journal of Multidisciplinary Engineering Science and Technology, 3 (2), (2016), 3903.

[5] Francisco Javier Rodríguez Varela, Sergio Fraire Luna and Oumarou Savadogo, Energies, 2 (2009) 944.

[6] Miriam Rosenbaum, Feng Zhao, Uwe Schröder and Fritz Scholz, Angew. Chem., 118 (2006) 1.

[7] Juan Manuel Mora-Hernández, Yun Luo and Nicolas Alonso-Vante, Catalysts, 6, 145 (2016) 1.

[8] A. Brouzgou, S. Q. Song and P. Tsiakaras, Applied Catalysis B: Environmental, 127 (2012) 371.

[9] Valentina Bambagioni, Claudio Bianchini, Andrea Marchionni, Jonathan Filippi, Francesco Vizza, Jacques Teddy, Philippe Serp, Mohammad Zhiani, Journal of Power Sources 190 (2009) 241.

[10] Yimin Zhu, Su Y. Ha and Richard I. Masel, Journal of Power Sources, 130 (2004) 8.

[11] S.Y. Shen, T.S. Zhao, J.B. Xu, Y.S. Li, Journal of Power Sources, 195 (2010) 1001.

[12] Antolini E., J. Power Sources, 170 (2007) 1.

[13] Jandee Kim, Toshiyuki Momma, Tetsuya Osaka, Journal of Power Sources, 189 (2009) 999.

[14] F. Vigier, C. Coutanceau, A. Perrard, E. M. Belgsir and C. Lamy, Journal of Applied Electrochemistry, 34 (2004) 439. 


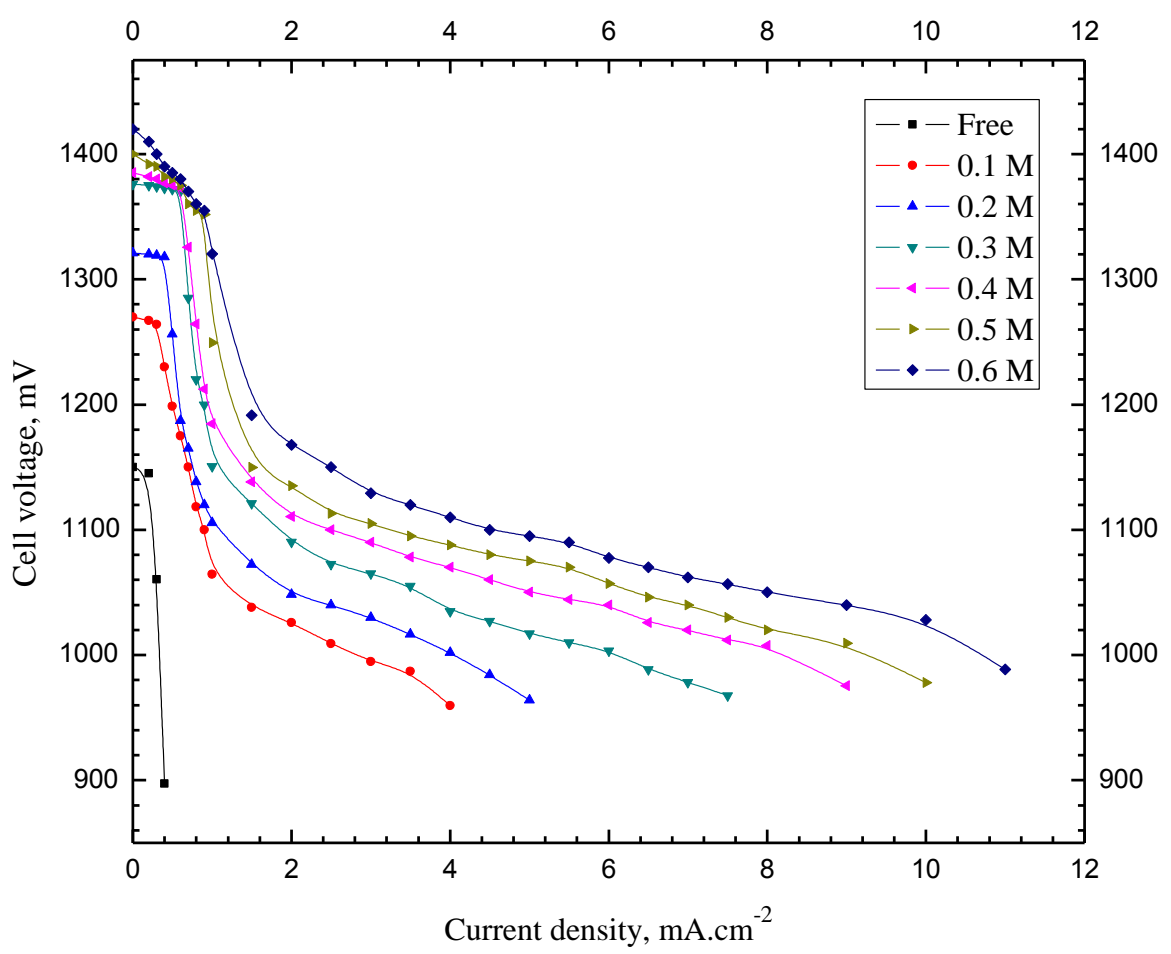

Fig. 1. Cell voltage, E, against current density, j, curves in absence and presence of different methanol concentrations, after 30 minutes of $\mathrm{Pt}$ modification.

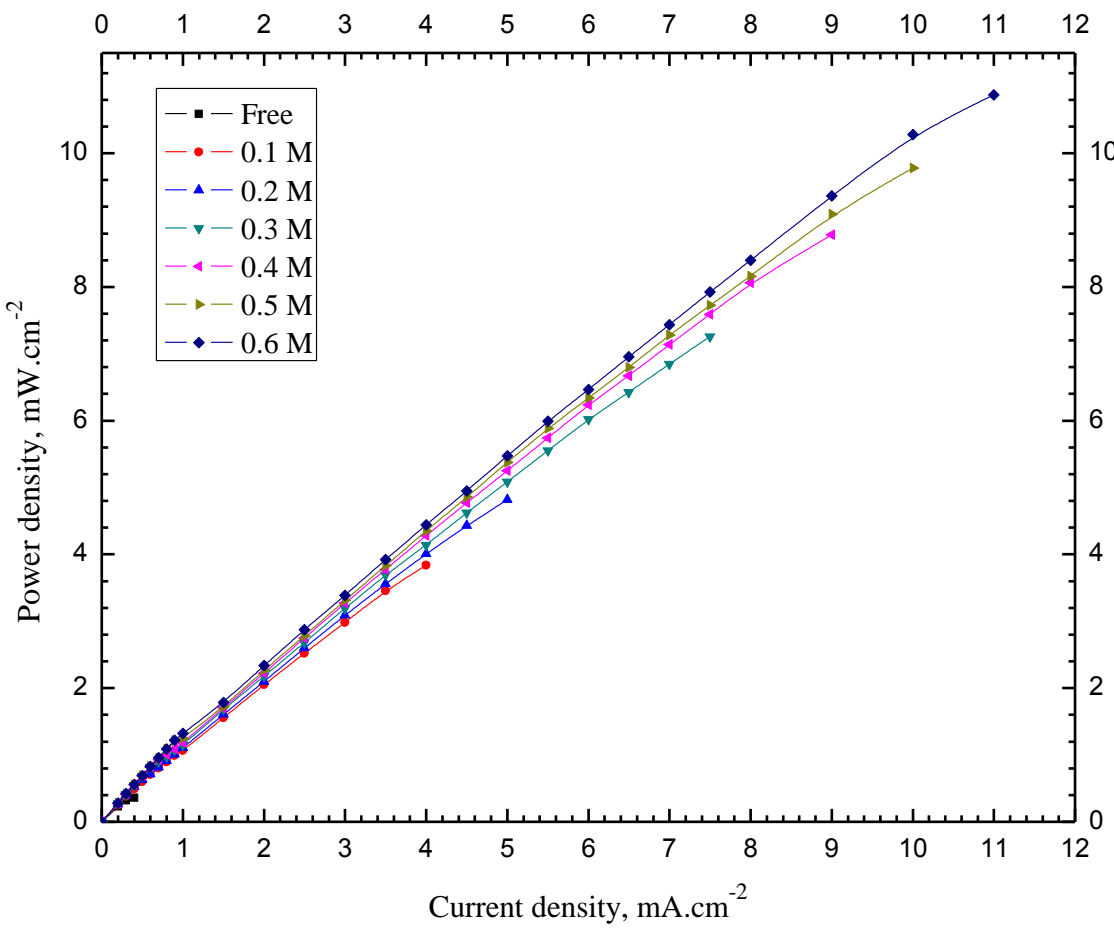

Fig. 2. Power density, $P$, against current density, $j$, curves in absence and presence of different methanol concentrations, after 30 minutes of $\mathrm{Pt}$ modification. 


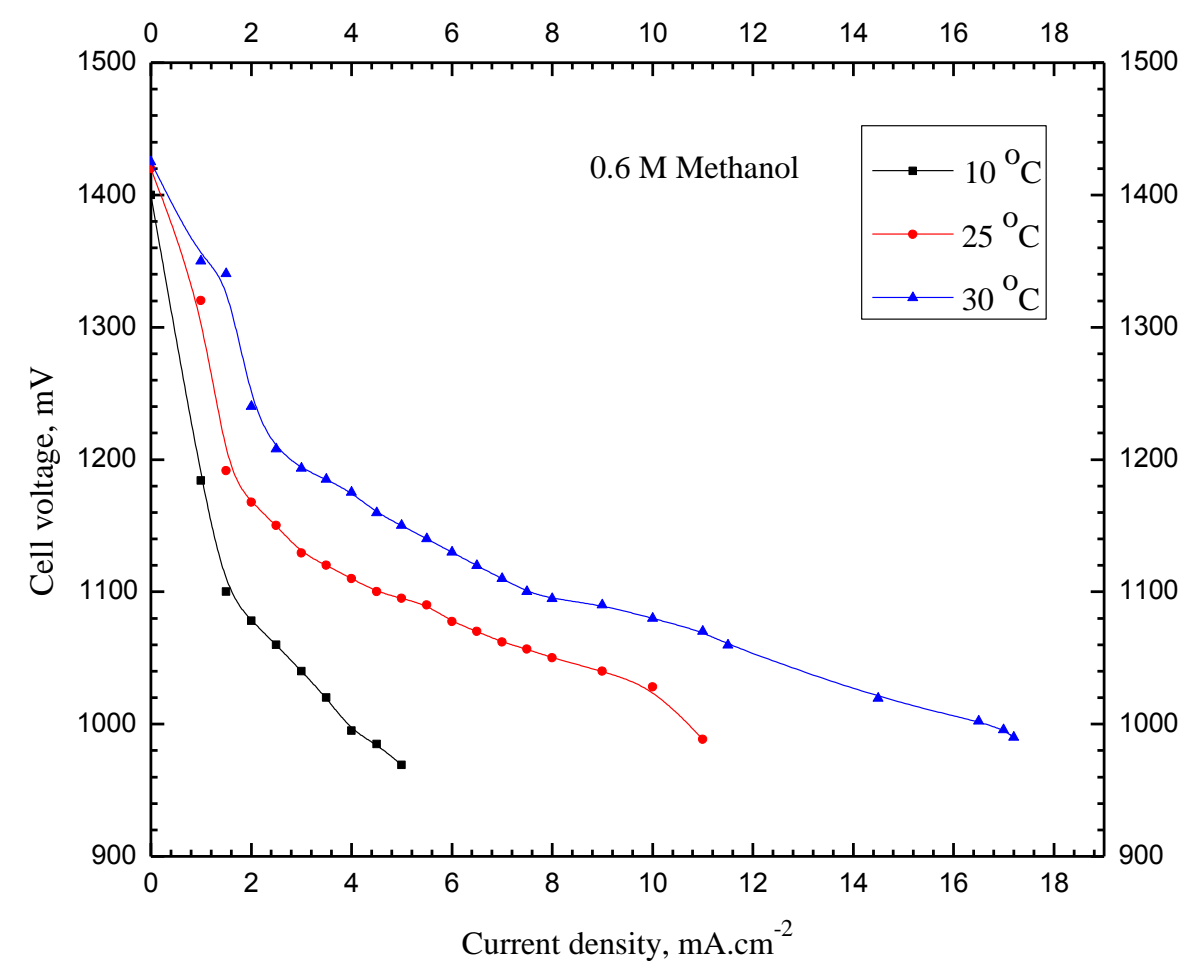

Fig. 3. Cell voltage, E, against current density, j, curves in $0.6 \mathrm{M}$ methanol at different temperatures, after 30 minutes of Pt modification.

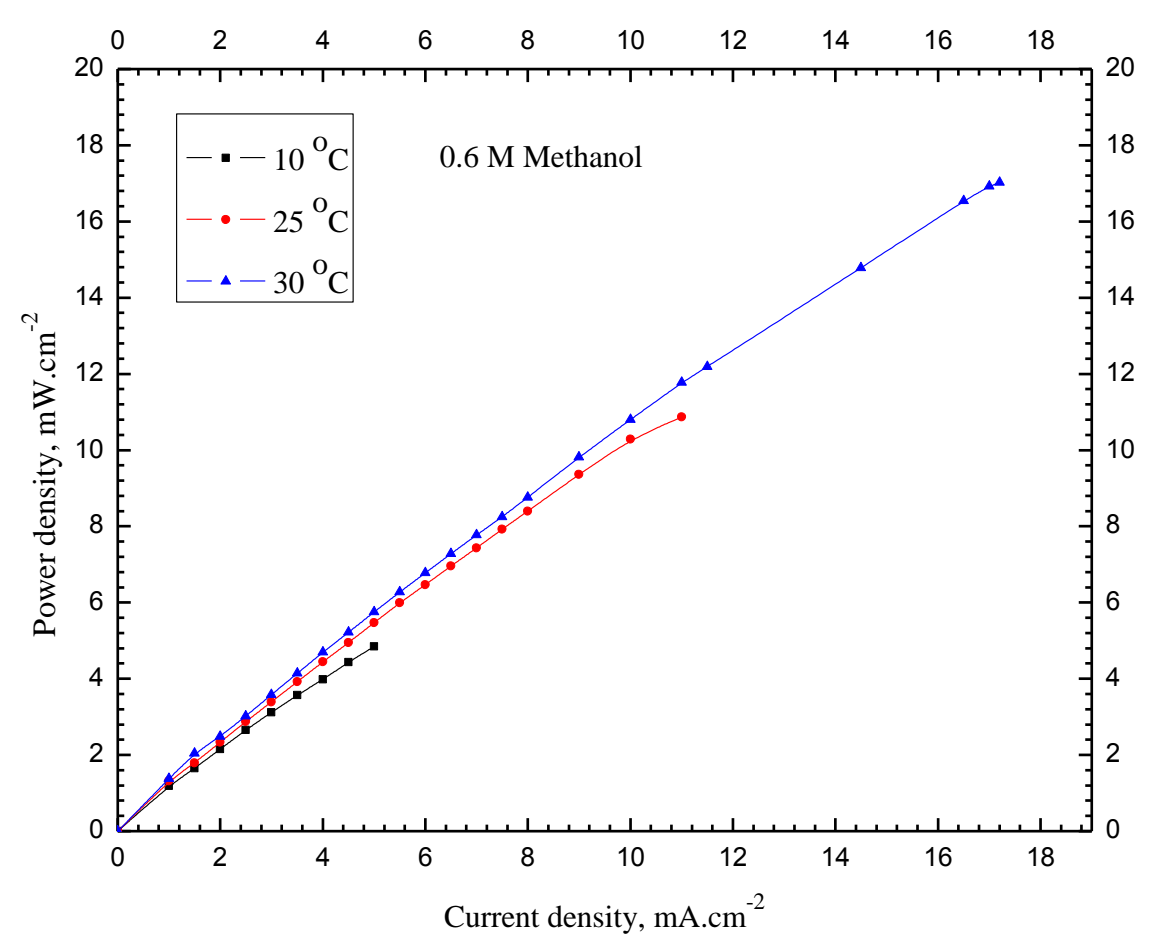

Fig. 4. Power density, $P$, against current density, j, curves in $0.6 \mathrm{M}$ methanol at different temperatures, after 30 minutes of Pt modification. 


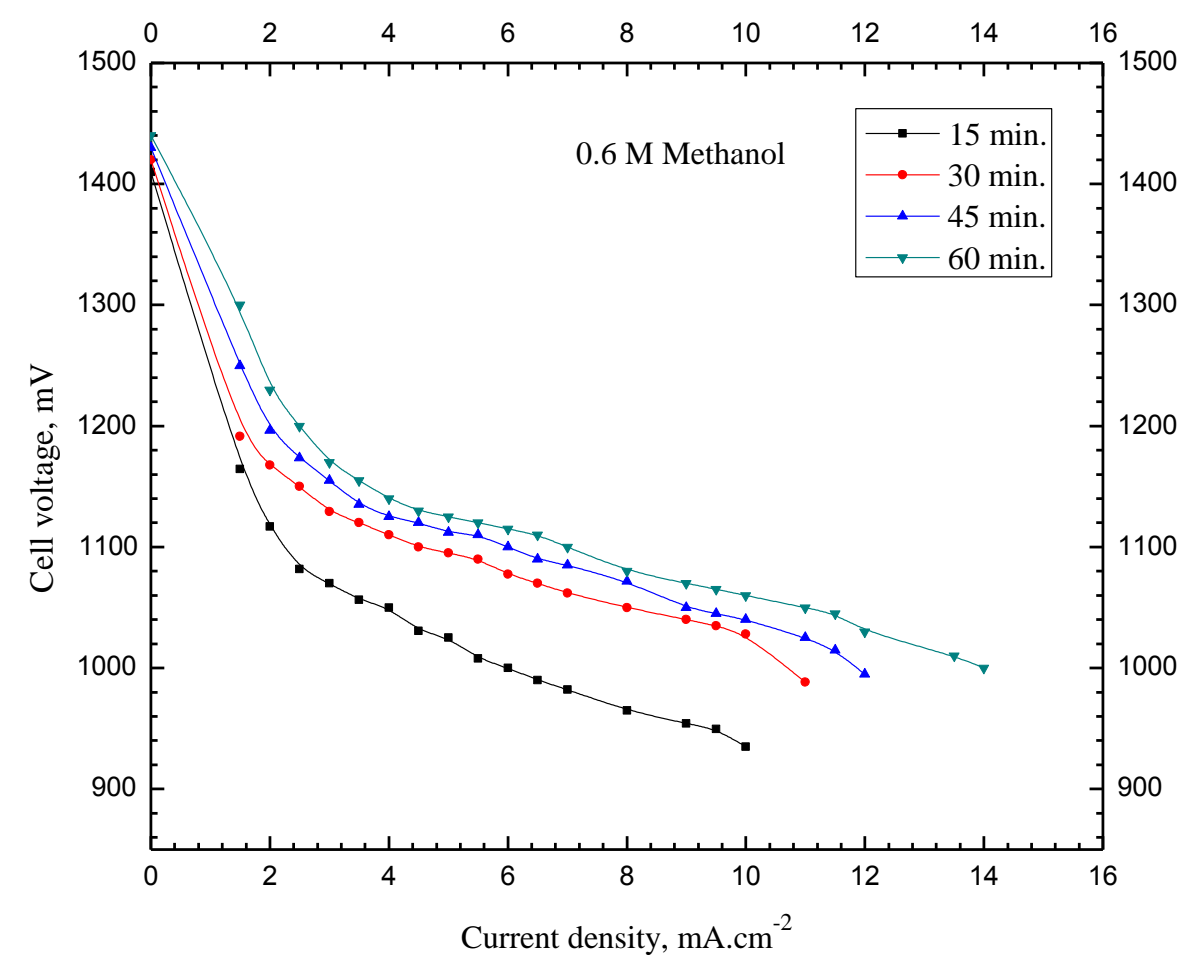

Fig. 5. Cell voltage, E, against current density, j, curves in $0.6 \mathrm{M}$ methanol, at different times of Pt modification, at $25{ }^{\circ} \mathrm{C}$.

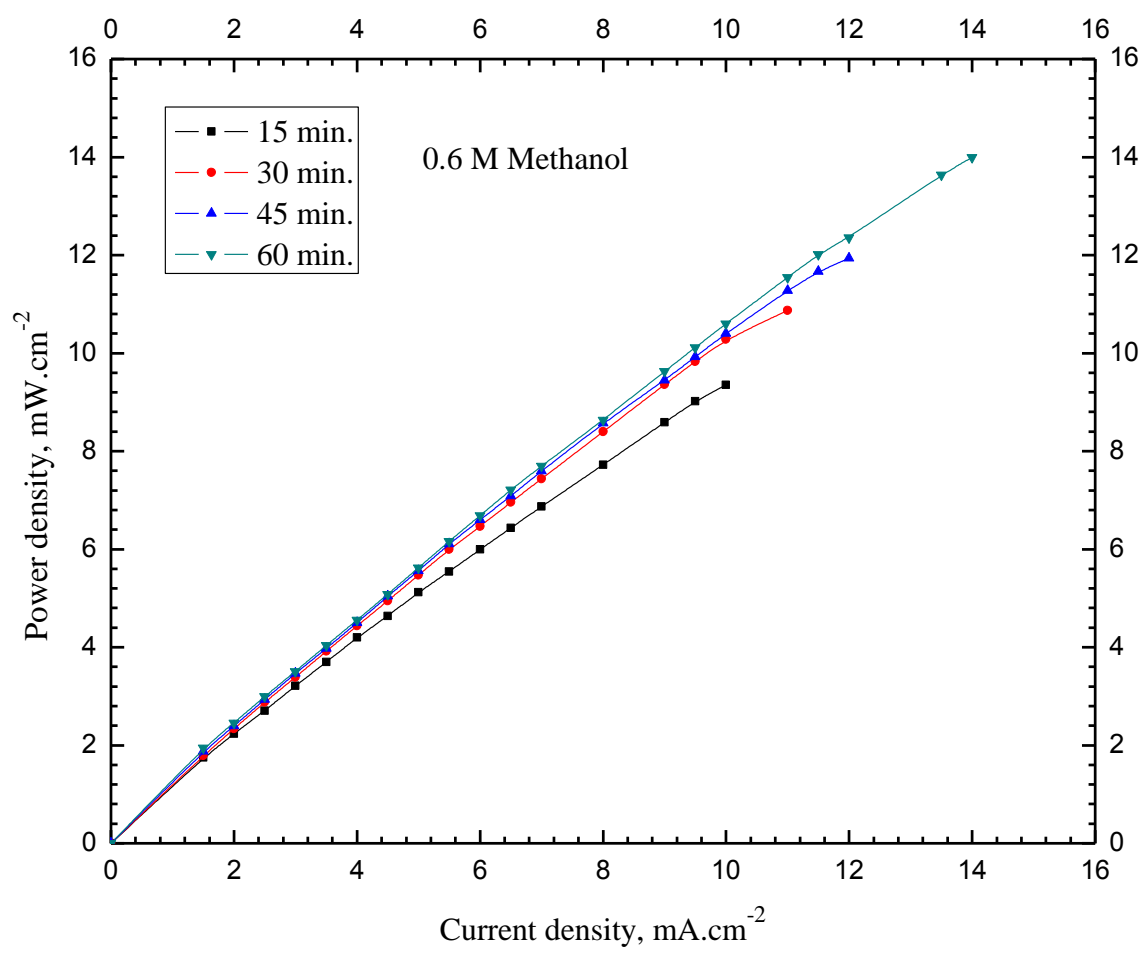

Fig. 6. Power density, P, against current density, j, curves in 0.6 M methanol, at different times of Pt modification, at $25^{\circ} \mathrm{C}$. 


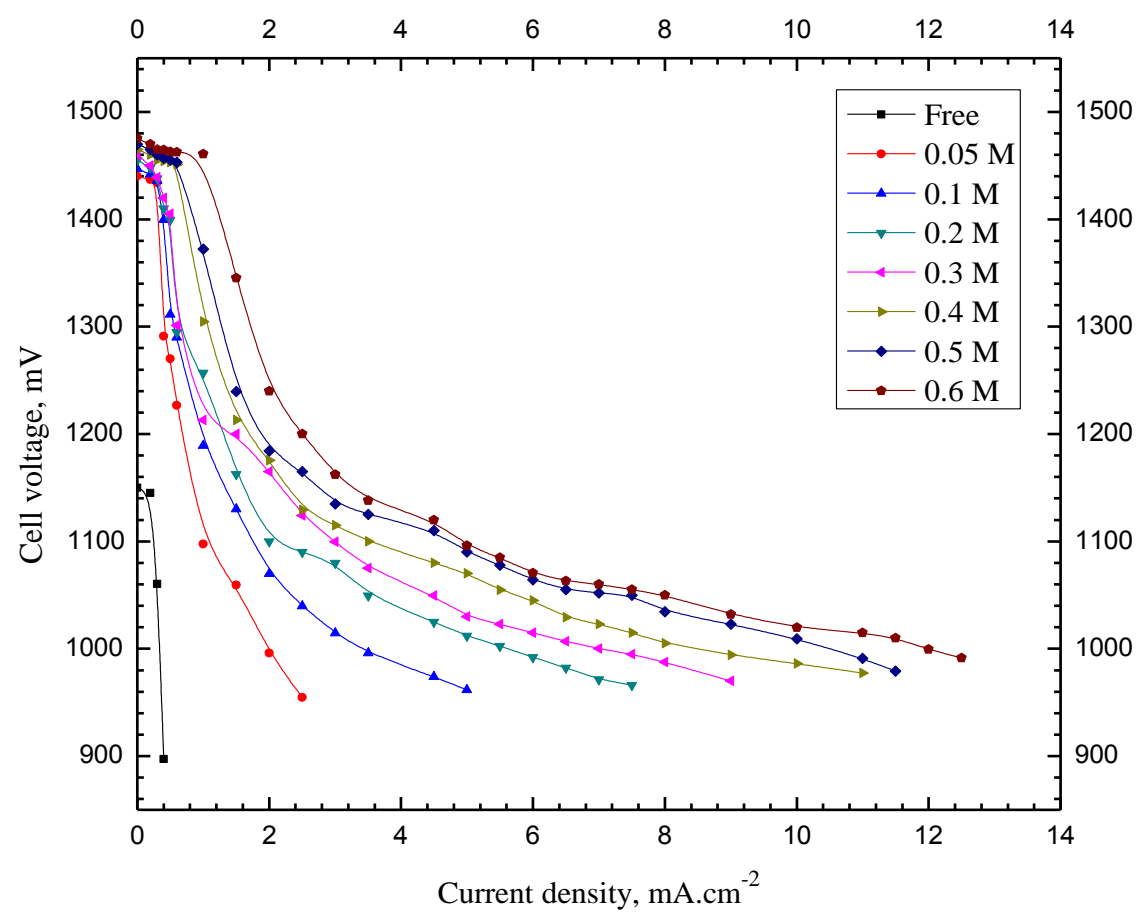

Fig. 7. Cell voltage, E, against current density, j, curves in absence and presence of different ethanol concentrations, after 30 minutes of $\mathrm{Pt}$ modification.

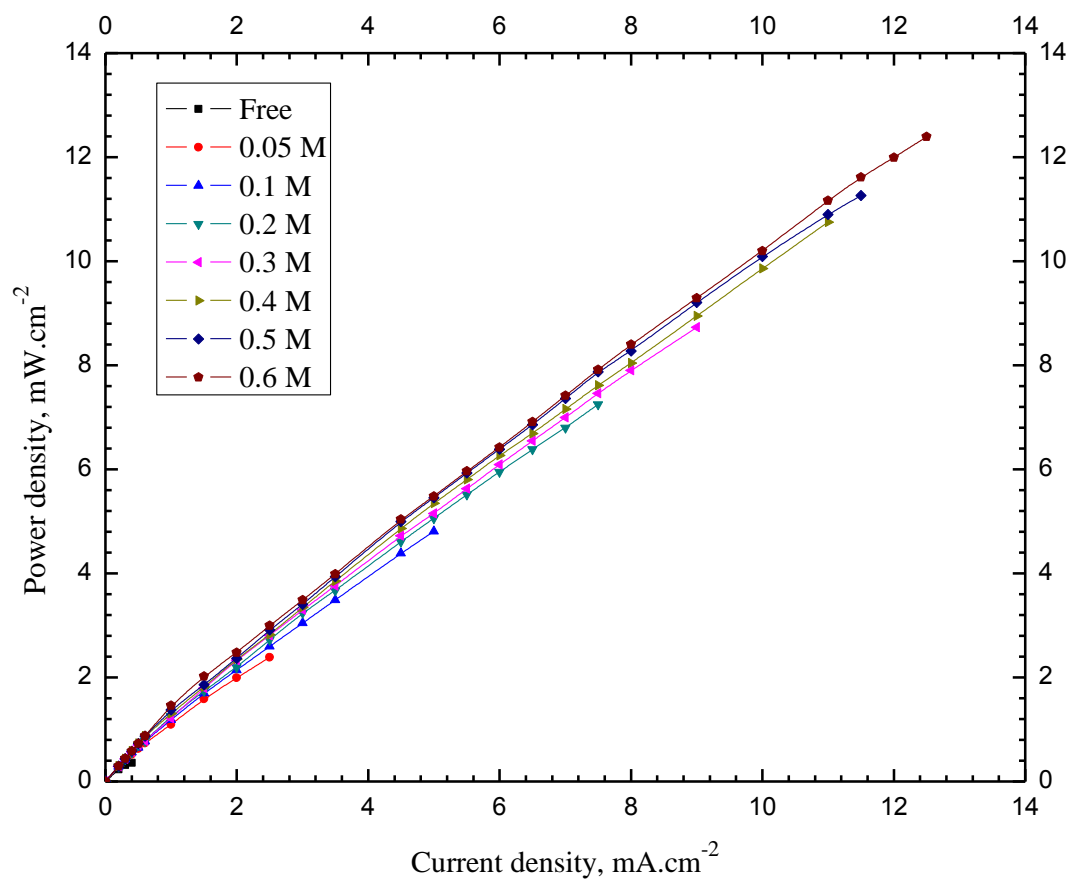

Fig. 8. Power density, P, against current density, j, curves in absence and presence of different ethanol concentrations, after 30 minutes of $\mathrm{Pt}$ modification. 


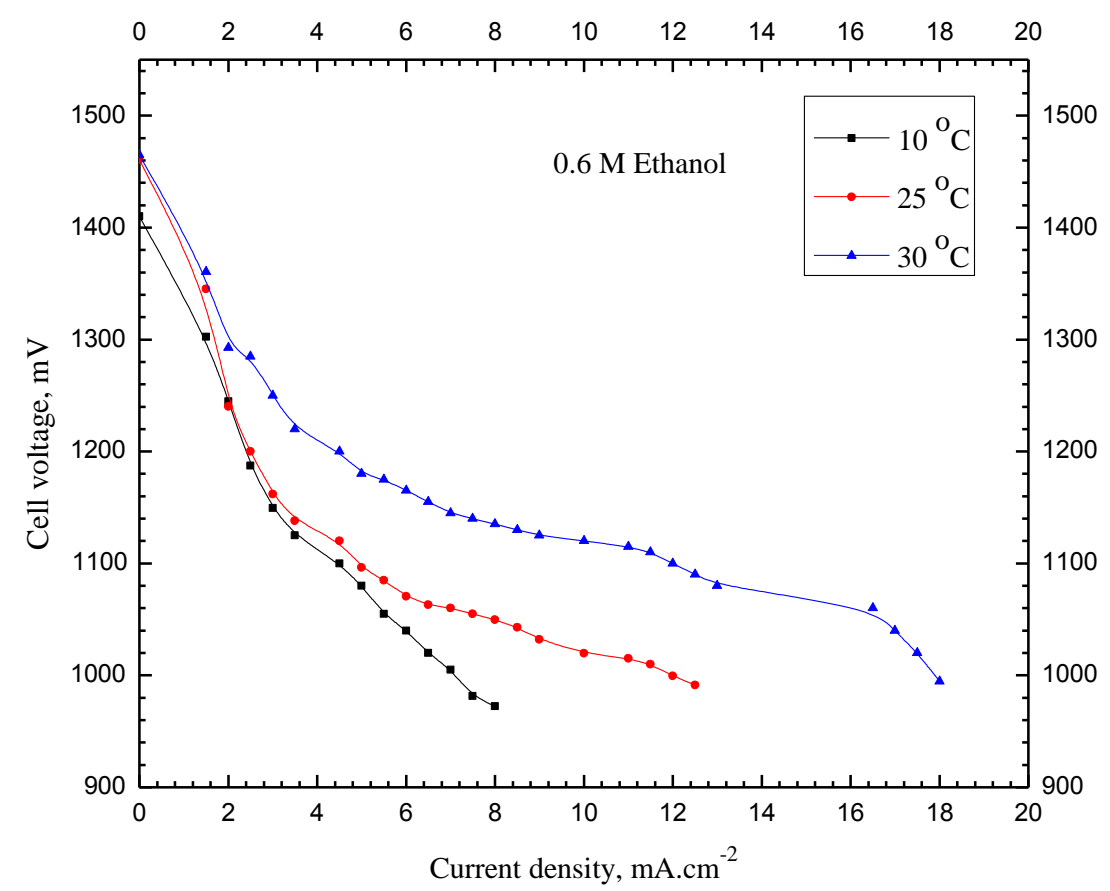

Fig. 9. Cell voltage, E, against current density, j, curves in $0.6 \mathrm{M}$ ethanol at different temperatures, after 30 minutes of Pt modification.

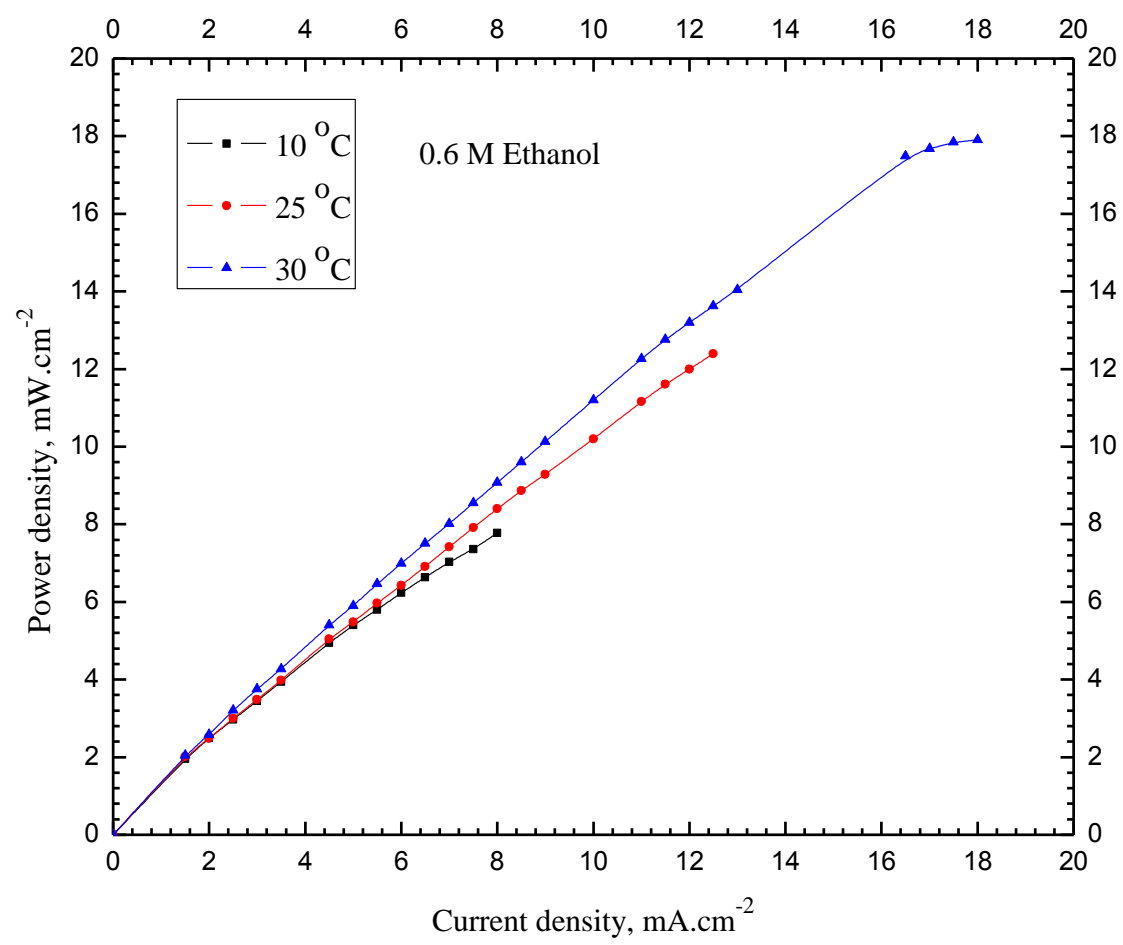

Fig. 10. Power density, $P$, against current density, j, curves in $0.6 \mathrm{M}$ ethanol at different temperatures, after 30 minutes of Pt modification. 


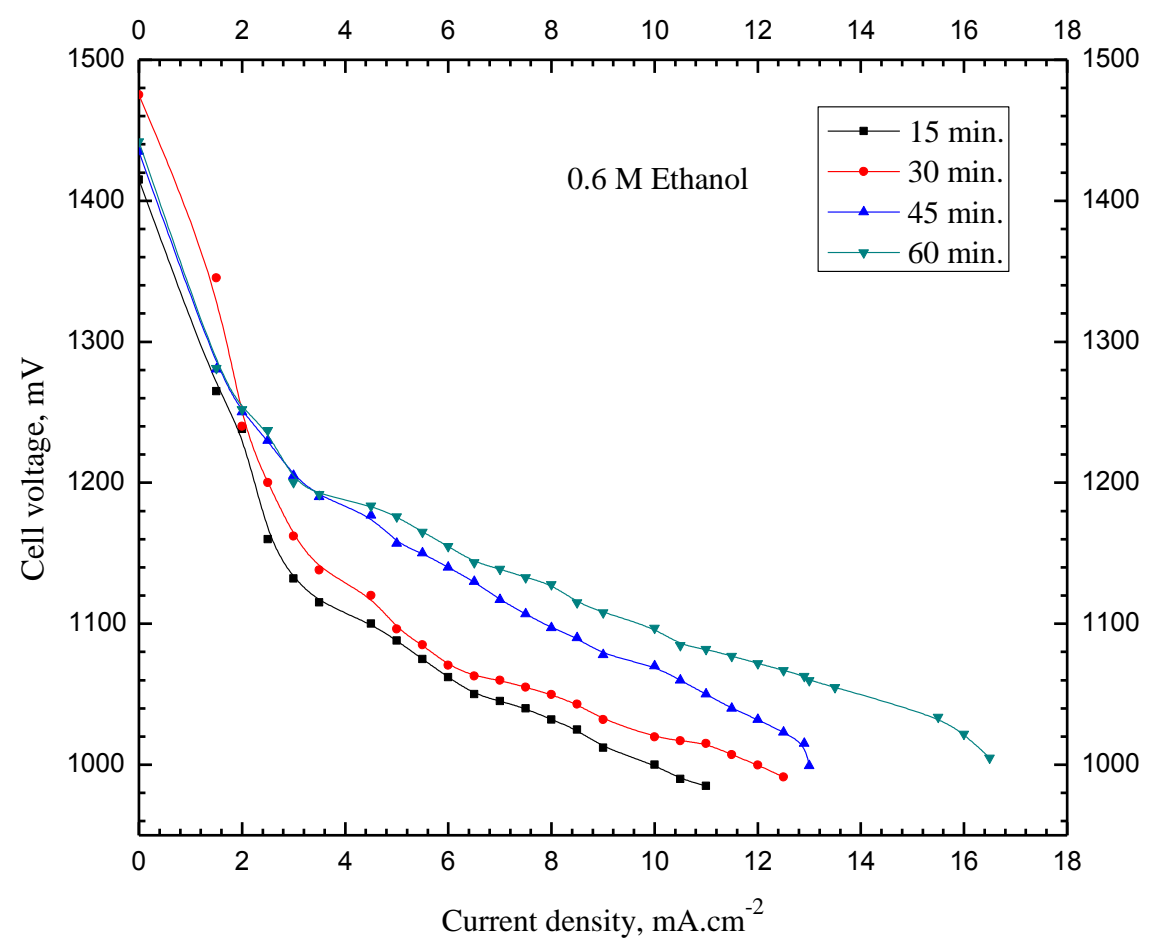

Fig. 11. Cell voltage, E, against current density $j$ curves in $0.6 \mathrm{M}$ ethanol, at different times of $\mathrm{Pt}$ modification, at $25{ }^{\circ} \mathrm{C}$.

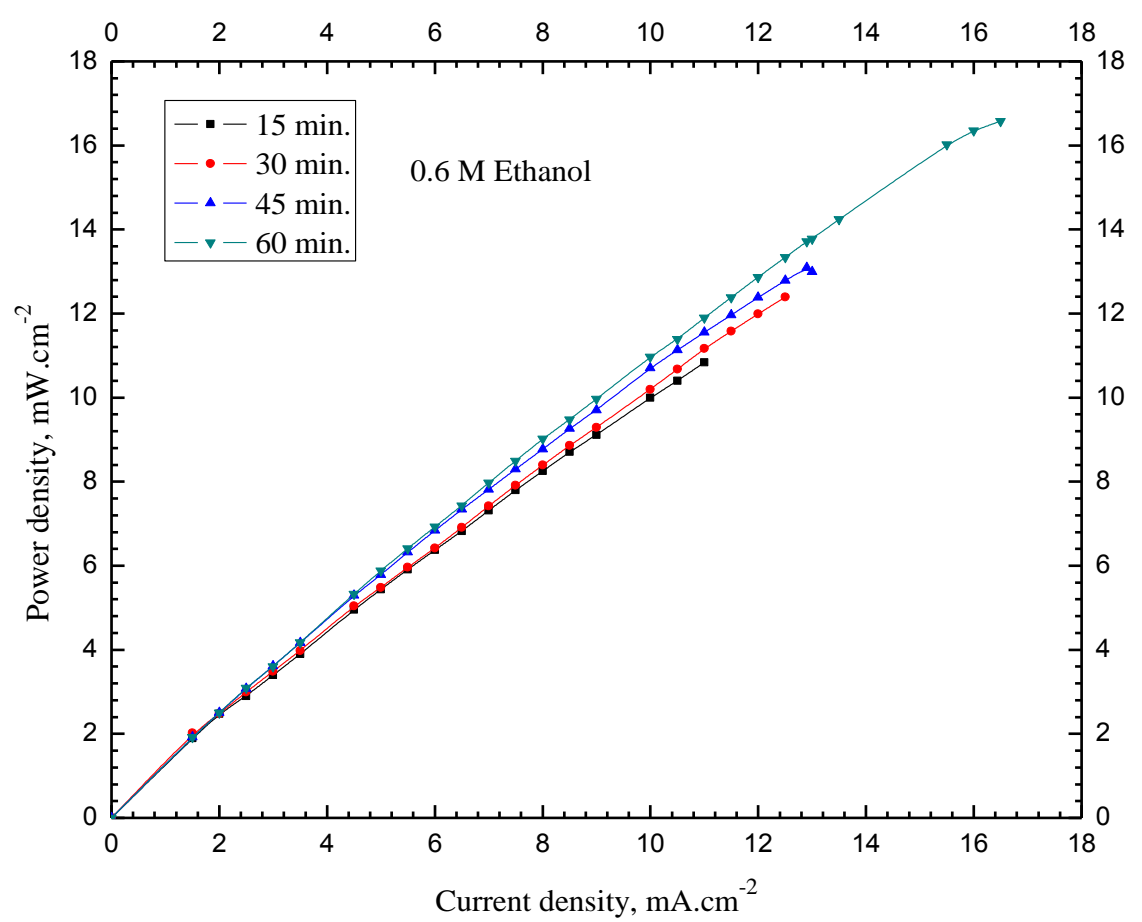

Fig. 12. Power density, $P$, against current density, $j$, curves in $0.6 \mathrm{M}$ ethanol, at different times of Pt modification, at $25{ }^{\circ} \mathrm{C}$. 


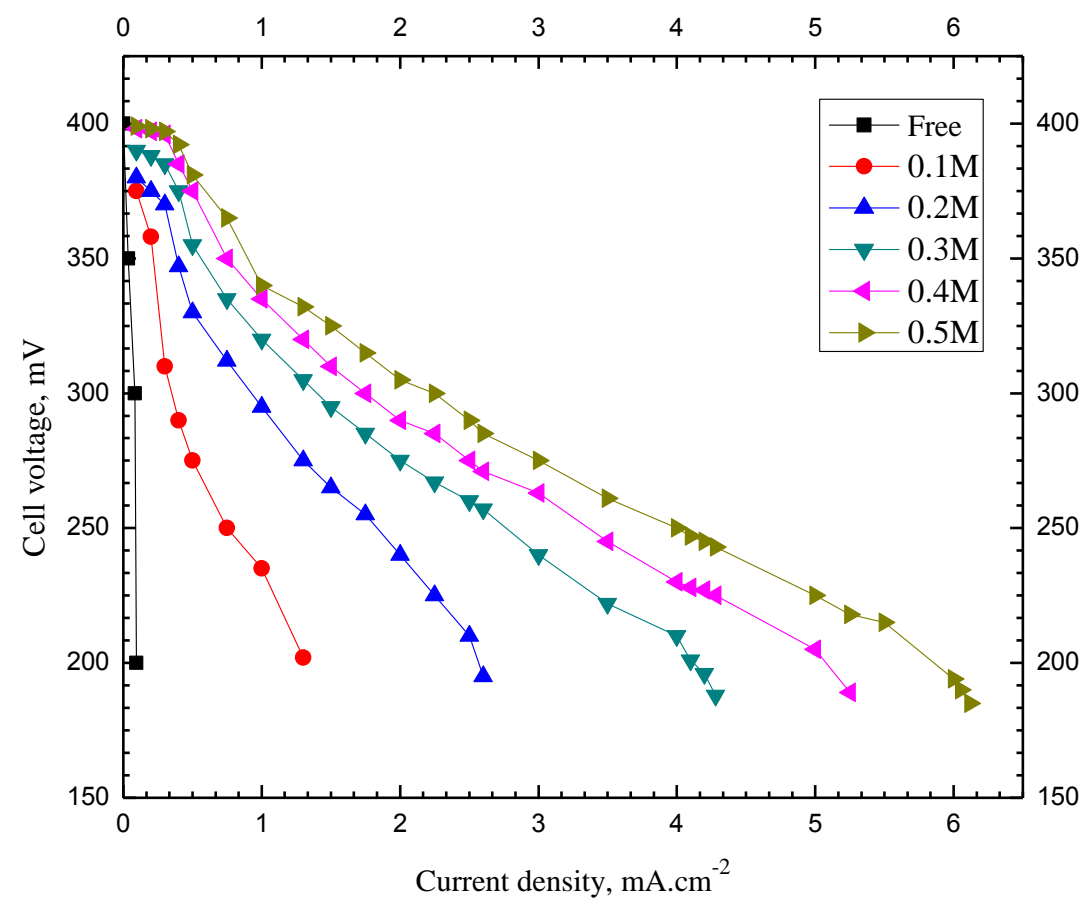

Fig. 13. Cell voltage, E, against current density, j, curves in absence and presence of different methanol concentrations, after 15 minutes of Pt modification in $0.1 \mathrm{M} \mathrm{KOH}$.

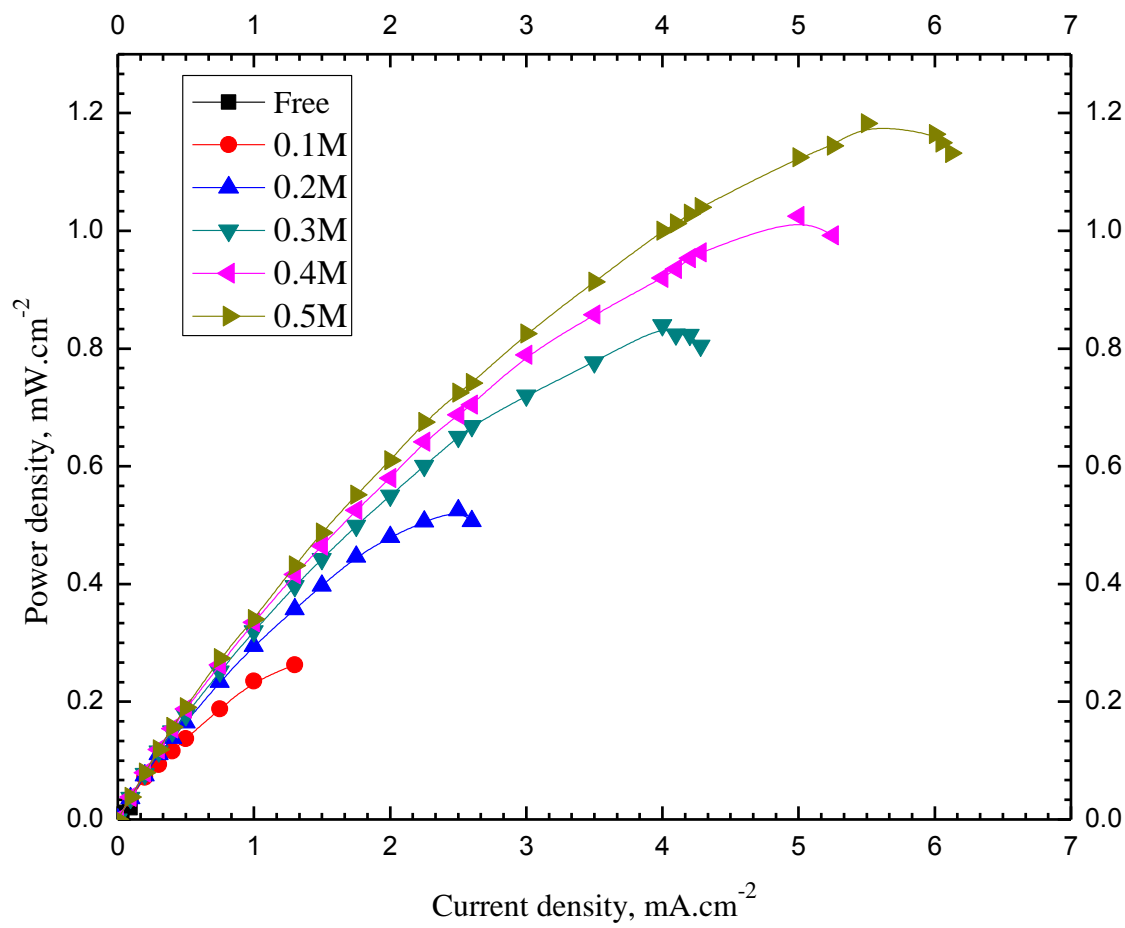

Fig. 14. Power density, $P$, against current density, j, curves in abscence and presence of different methanol concentrations, after 15 minutes of Pt modificationin $0.1 \mathrm{M} \mathrm{KOH}$. 


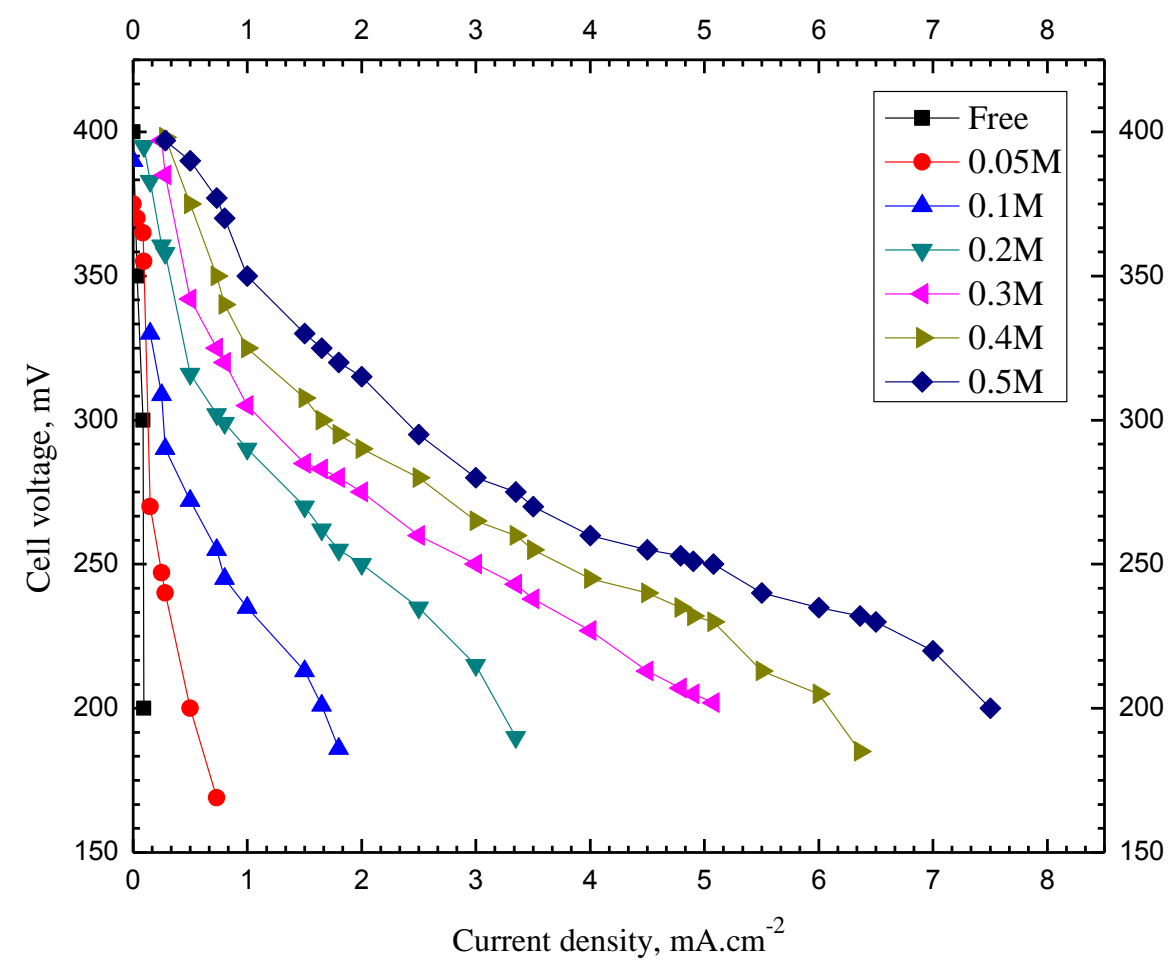

Fig. 15. Cell voltage, E, against current density, j, curves for absence and presence of different ethanol concentrations, after 15 minutes of Pt modification in $0.1 \mathrm{M} \mathrm{KOH}$.

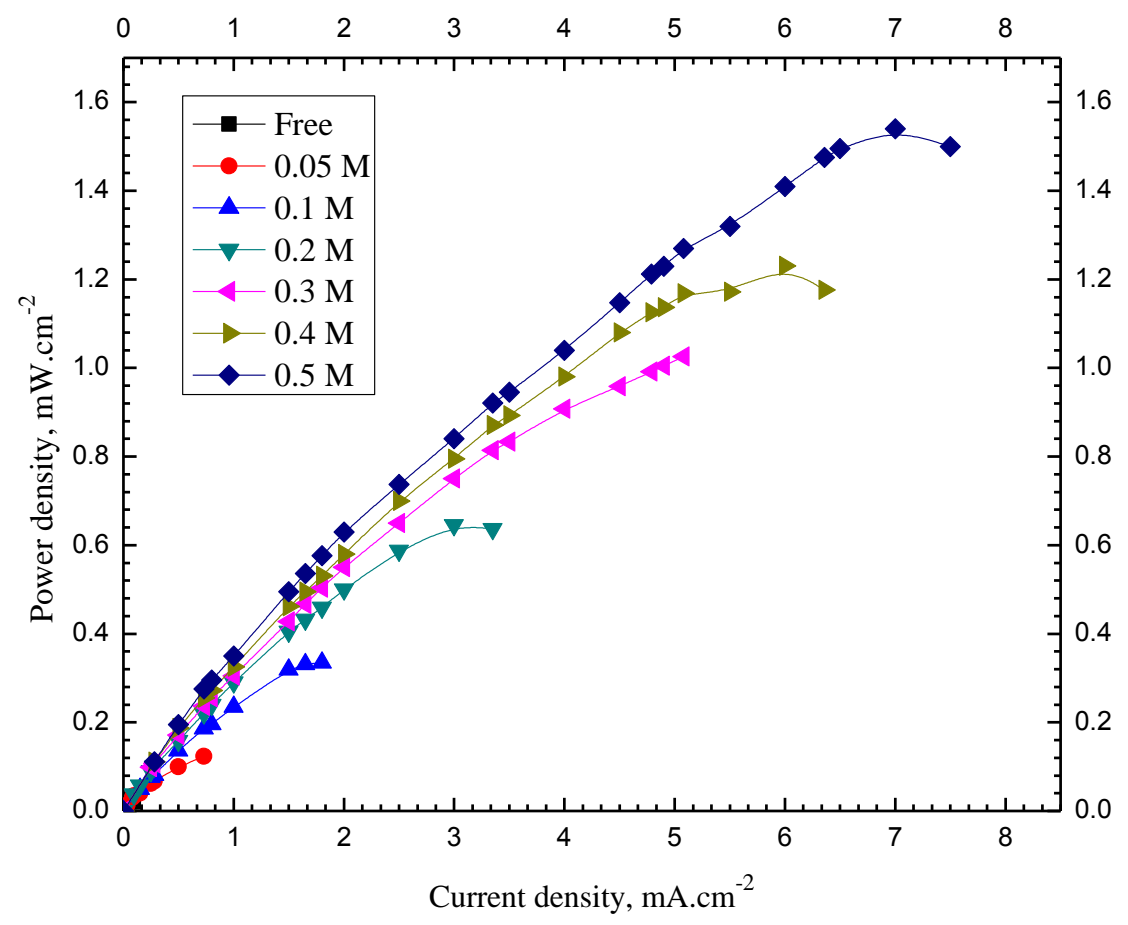

Fig. 16. Power density, $P$, against current density, j, curves for absence and presence of different ethanol concentrations, after 15 minutes of Pt modificationin $0.1 \mathrm{M} \mathrm{KOH}$. 


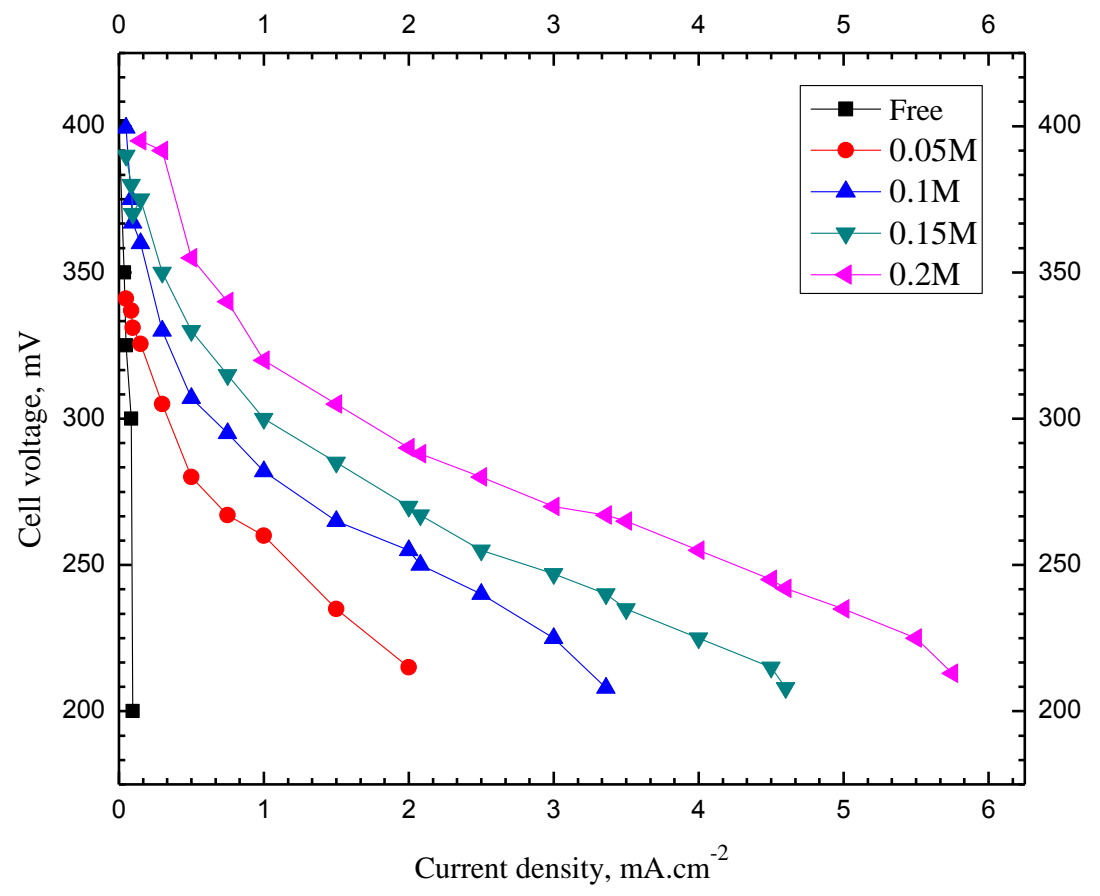

Fig. 17. Cell voltage, E, against current density, j, curves for absence and presence of different methanol concentrations, after 15 minutes of $\mathrm{Pt}$ modification in $0.05 \mathrm{M} \mathrm{KOH}$.

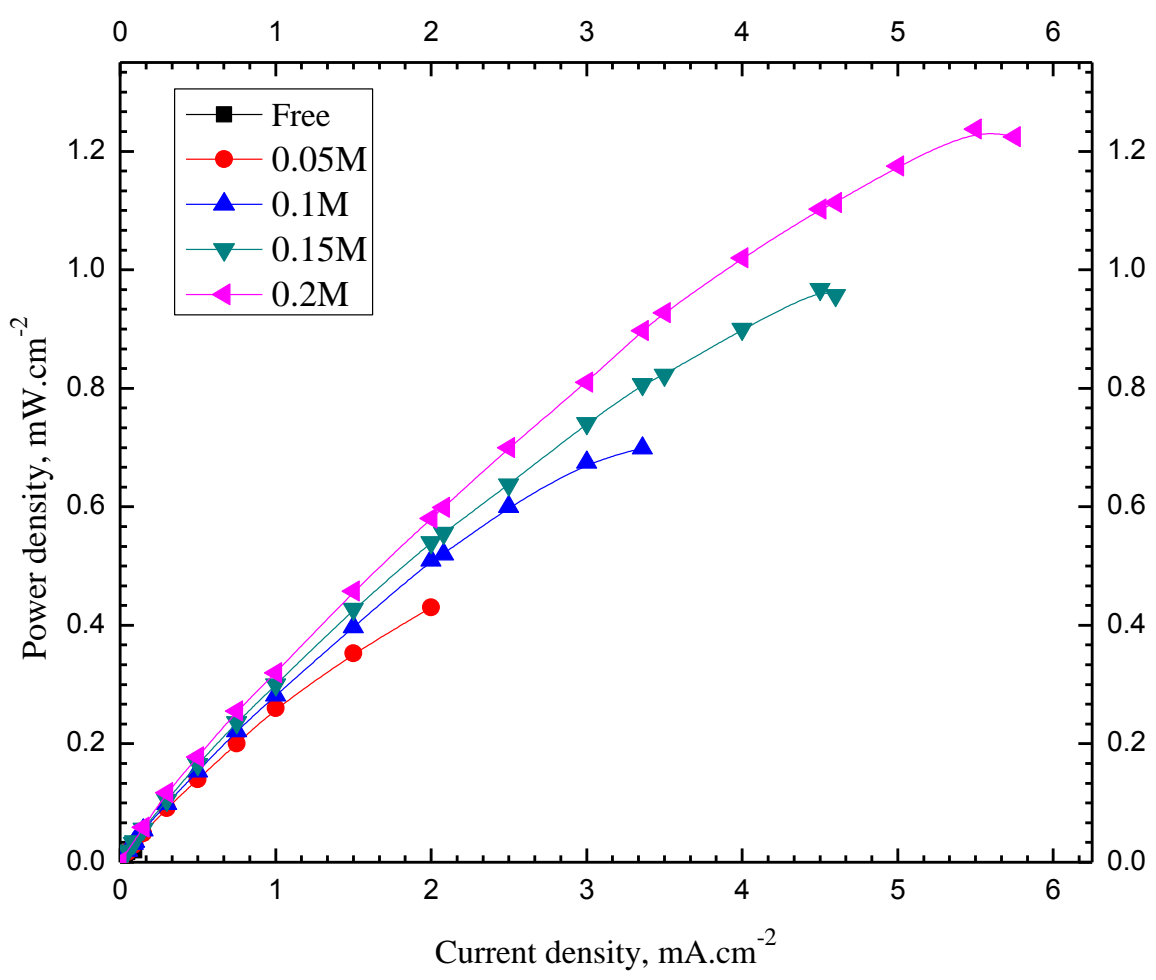

Fig. 18. Power density, $P$, against current density, j, curves for absence and presence of different methanol concentrations, after 15 minutes of Pt modificationin $0.05 \mathrm{M} \mathrm{KOH}$. 


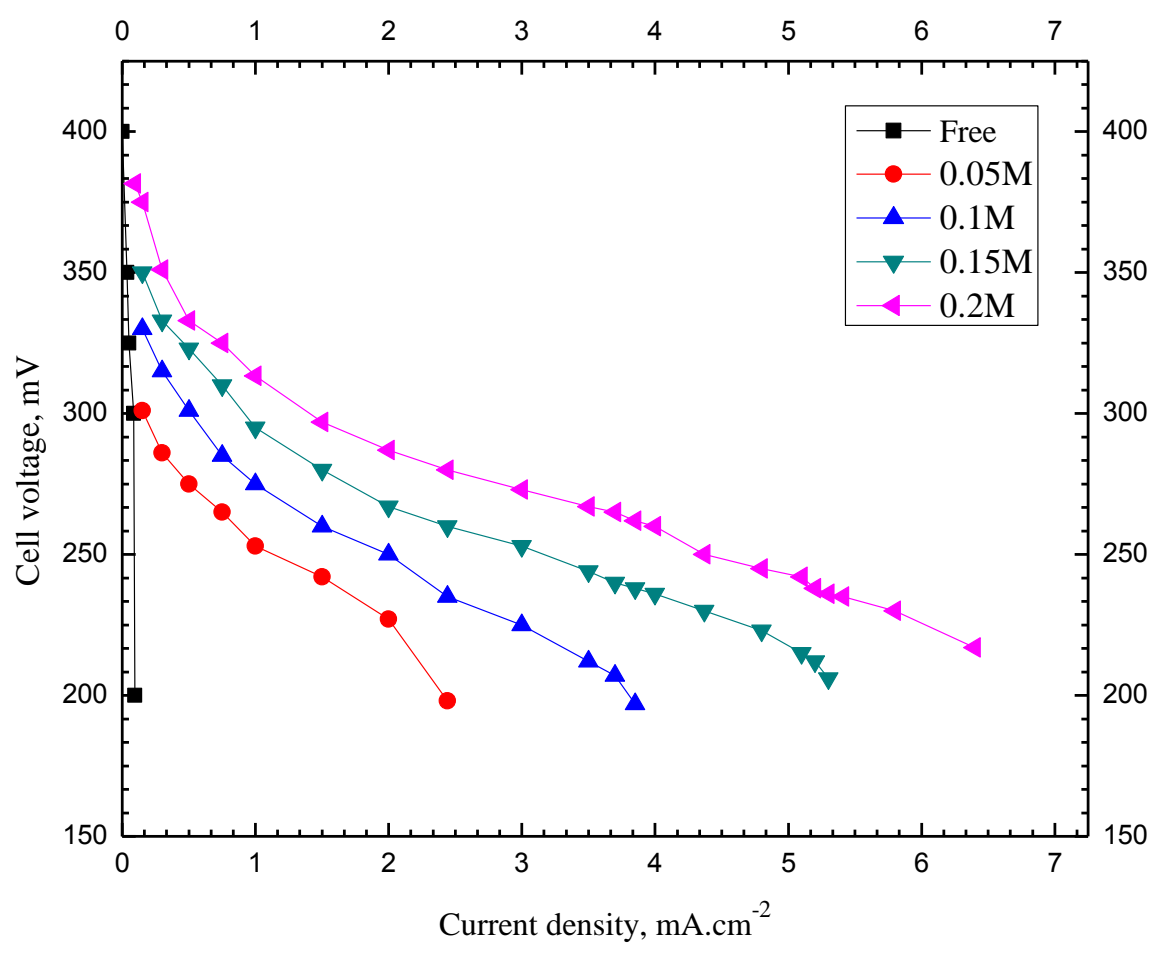

Fig. 19. Cell voltage, E, against current density, j, curves for absence and presence of different ethanol concentrations, after 15 minutes of $\mathrm{Pt}$ modification in $0.05 \mathrm{M} \mathrm{KOH}$.

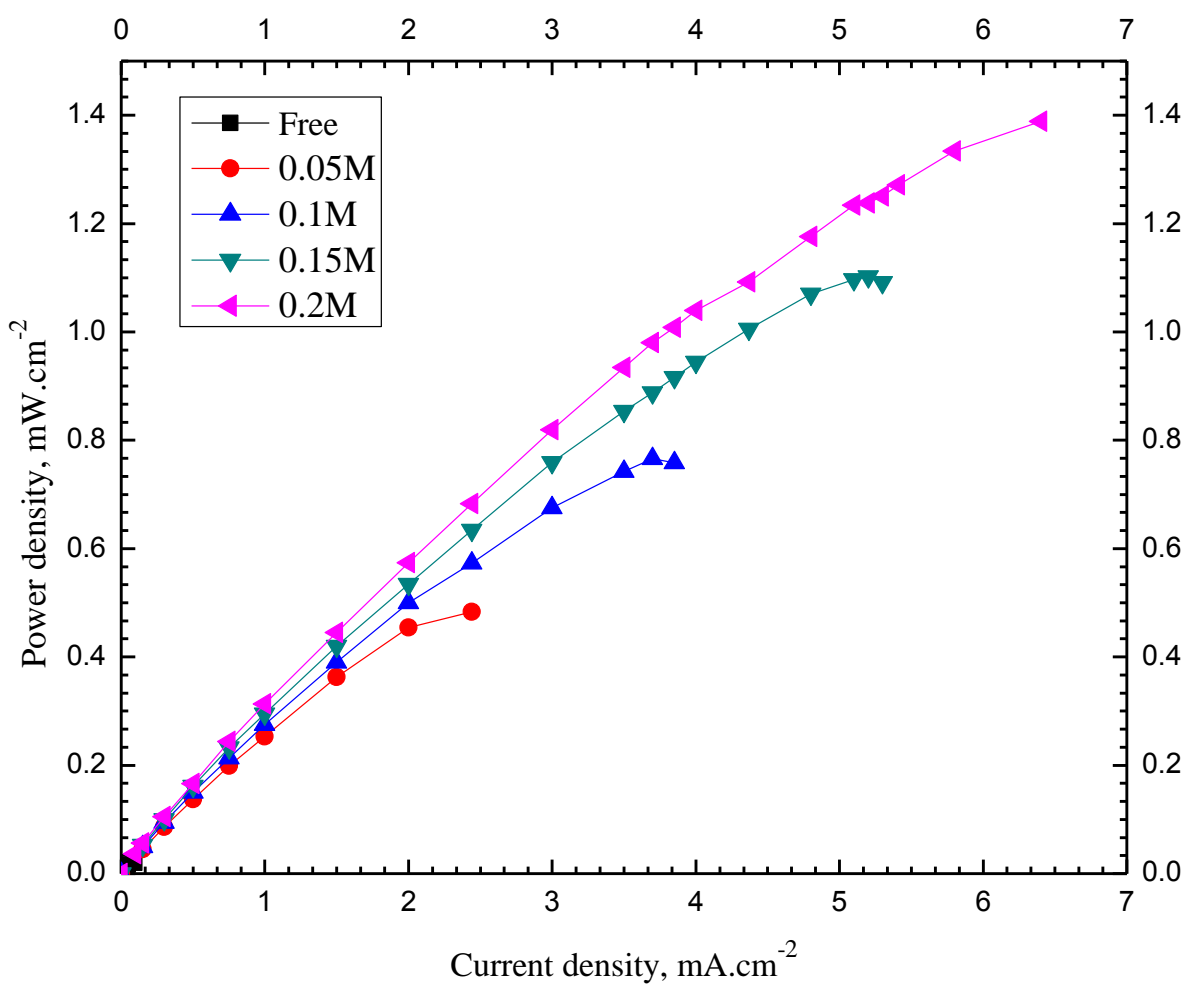

Fig. 20. Power density, $P$, against current density, j, curves for absence and presence of different ethanol concentrations, after 15 minutes of $\mathrm{Pt}$ modificationin $0.05 \mathrm{M} \mathrm{KOH}$. 